\title{
Materials and manufacturing environmental sustainability evaluation of apparel product: knitted T-shirt case study
}

\author{
Md Mashiur Rahman Khan and Md Mazedul Islam*
}

\begin{abstract}
In this paper, evaluation of base materials and manufacturing environmental sustainability of selected branded T-shirt products made by Bangladesh is presented. The study is based on performing various eco-friendliness tests for the product base materials and evaluation though a standard tool named Higg Index. For this study, selected apparel branded T-shirt products from renowned brand, namely B, C, D, E, and F, and a researcher-developed BUTex-Innovation brand A are taken into consideration. Better environmental sustainability results, i.e., higher score, is obtained by $A, B, C$, and $D$ branded T-shirts, but local branded product of $E$ and $F$ resulted in poor environmental sustainability with lower scores in terms of product eco-friendliness tests and High Index assessment tool. Besides, many weaknesses and opportunities for improvement of environmental sustainability in materials and manufacturing stages are identified and suggested to lead the textiles and clothing sectors towards sustainable growth.
\end{abstract}

Keywords: Clothing products; Base materials; Knitted T-shirt; Higg index; Environmental sustainability

\section{Background}

Sustainability is the major concern in the age of the modern world. For the textile and apparel sector, it has been a burning issue for many related concerned bodies. Challenges faced by the apparel manufacturers and retailers, brands with many incidents such as the Rana Plaza building collapse, the Tazreen garments fire tragedy in Bangladesh, and the crisis in Cambodia, led the clothing industry giants, nonprofit organizations, fashion designers, manufacturers, and consumers to be well aware towards sustainable textiles and clothing business practices. Over the past few years, increasing awareness of the environmental and social concerns surrounding the fashion industries and consumers has led to a rise in the implementation of sustainability initiatives. There has been a growing concern over apparel brands in improving their environmental impact and the social responsibility throughout their supply chains (Allwood et al. 2006). Most of the textiles and clothing product used by the consumer has a significant impact on the environment. For example, according to a study, one

\footnotetext{
* Correspondence: mazed.butex77@gmail.com

Department of Apparel Engineering, Bangladesh University of Textiles, Tejgaon Dhaka-1208, Bangladesh
}

0.5-lb cotton T-shirt requires 700 gallons of water during processing, uses $0.2 \mathrm{lb}$ of fertilizers and 0.01 -lb pesticides, and emits $6 \mathrm{lb}$ of $\mathrm{CO}_{2}, 1.2 \mathrm{lb}$ of fossil fuels, and $0.11 \mathrm{lb}$ of other gases. One $0.5-\mathrm{lb}$ pound $\mathrm{T}$-shirt does 18.3 pounds of $\mathrm{CO}_{2}$ emission on average from washing and dyeing 50 times in US (Fletcher and Grose 2012; USagain, 2015). Many consumers today do not know the extent to which these products impact the environmen$t$-low or high. They must account for the environmental impacts of the materials she uses, the resulting waste of the forms she chooses, how products are produced and packaged, where they will be made and then sold, causing the energy use for transportation, how consumers may use and dispose of the product (Adams and Frost 2008). A product is thought to be eco-sustainable if it is manufactured, used, and disposed of in a manner that would not harm the environment when compared to a product that was manufactured and used without any environmental concern. However, consumers have become more conscious of these impacts and are spelling out their preferences for eco-friendliness, thereby forcing the manufacturer to adopt clean technologies all along the supply chain to produce environmentally friendly products (Challa 2014). Environmental sustainability refers to

\section{黑 Springer}


the ability of something to continue without upsetting the earth's ecological balance. Sustainable apparel products can be defined as a part of the growing design philosophy and trend of sustainability, the goal of which is to create a system which can be supported indefinitely in terms of environmentalism and social responsibility (Adams and Frost 2008). Environmental sustainability in business refers to longevity but in terms of which natural resources the production process might draw upon, how resources are used and replenished, the overall impact of the final production on the environment, and where the product ends up following its disposal. The textile and apparel products impact the environment at every point along the product's lifecycle (Fletcher 2008). However, rapid growth in the textiles and clothing industry sector is playing a vital role in the economy of Bangladesh. Despite the growing necessity of environmental practices in the apparel industry, little research has explored methods and standard tools to guide apparel designers, manufacturers, merchandisers, and consumers in adapting environmental issues in their works. Many designers do not recognize how their designs impact the environment. The role of the designer must expand dramatically in light of current environmental concerns with the contamination and destruction of the ecosystem (DEFRA 2010). Today's designer, manufacturer, merchandiser, and consumer must be well informed on a vast array of topics, from methods of production to governmental regulations to life cycle analysis. They must account for the environmental impacts of the materials' uses, the resulting waste of the forms they choose, how products are produced and packaged, where they will be made and then sold, the causing energy use for transportation, and how consumers may use and dispose of the product (Goworek 2011). All products that are manufactured cause environmental degradation, either during manufacture, use, or disposal. This can be evaluated by looking at the different phases of the product's life cycle and taking action at the phases where it will be most effective to reduce the environmental impact. Among many techniques to study the eco-impact of products, the life cycle assessment is most widely used one. LCA examines products from initial stage to the final stage, covers the entire life cycle, and also examines eco-impact during the whole lifetime (Muthu et al. 2012). However, the life cycle of a product is long and complicated, covering many areas with many people involved in each phase. A remedial measure or policy may not be possible to address this aspect, but a variety of voluntary and mandatory tools will help to achieve this objective. These include eco-friendly tests for related clothing products, economic instruments, bans on certain substances, environmental labeling, voluntary agreements, and product design guidelines (IPP 2014). Hence, there is a growing need to evaluate the environmental sustainability of apparel products by standard methods, tools, and techniques to minimize the environmental impact. The Higg Index by the Sustainable Apparel Coalition is such a standard tool by which the environmental sustainability of apparel products could be evaluated. This study attempts to identify and analyze a number of these issues related to apparel product sustainability focusing on materials and manufacturing environmental sustainability by taking several local and foreign branded knitted T-shirts into consideration as a case study.

\section{Literature review}

The clothing industry is a popular industry among consumers, but it has great effects on many environmental, social, and governance concerns (Challa 2014). The textile industry prepares the base materials and the fashion, and the apparel industry converts these materials to suit the desires and needs of consumers; both industries are responsible for high utilization of energy, water, chemicals, and resources from cotton to petroleum (Niinimäki and Hassi 2011). The poor on-site conditions of the textile factories and working environment have caused many problems for the workers and operators, forming the basis for social reforms. In addition, the precarious supply chain upon which many manufacturers rely to develop apparel products can cause many problems for merchandisers and retailers for sustainable apparel product manufacturing.

\section{Sustainable apparel product}

Sustainability is defined as the design of human and industrial systems to ensure that humankind's use of natural resources and cycles do not lead to diminished quality of life due either to losses in future economic opportunities or to adverse impacts on social conditions, human health, and the environment (Lewis and Chem 2006). Environmental science defines sustainability as the quality of not being harmful to the environment or depleting natural resources and thereby supporting longterm ecological balance. The sustainable textile products can be defined as the textile products produced using raw materials, energy, various resources, and other ingredients which are derived from renewable resources that cannot be exhausted and consequently do not affect the next generation (Muthu et al. 2010). To achieve sustainable development, designers need to be aware of environmental impacts and incorporate environmental awareness into the design (Adams and Frost 2008). Product sustainability is the easiest aspect to alter for an apparel brand, as this is where a company has the most and direct control through design and product development. Transforming product sustainability may be achieved via various aspects such as fiber/textile selection, 
processing methods, use behaviors, and reuse/recycle strategies. Material selection is often the first step that designers and product developers will take in reducing the environmental impact of the garment. Environmentally preferred fibers/textiles can significantly reduce the environmental impact and increase the resourcefulness of an apparel product throughout the garment life cycle without changes to design practice or product development processes (Allwood et al. 2006).

\section{Environmental impact of textiles and clothing products}

The apparel industry has many negative environmental and social impacts that are complex and occur at different stages of the apparel life cycle. The development of fast fashion has amplified the impacts due to the increased volume of apparel produced and sold at low prices (Laursen et al. 2007). The apparel has a long and complicated production chain consisting of many phases including resource production and extraction, fiber and yarn manufacturing, textile manufacturing, apparel assembly, packaging, transportation and distribution, consumer use, recycling, and ultimate disposal (Islam and Khan 2014). The environmental impacts of apparel are varied across the phases, difficult to assess for individual garments, and are subject to the type of raw material used, dyeing and laundering. The major environmental impacts associated with the production and use of apparel throughout its life cycle include wastewater emissions from dyeing, finishing, and washing processes, increase in pollution, solid waste production, and significant depletion of resources from consumption of water, fossil fuels, and raw materials (Islam et al. 2014). Energy is used for laundering, transportation, operations of machines for various processes, the production of primary materials, especially man-made fibers such as polyester (a petroleum-based product), and yarn manufacturing of natural fibers such as cotton (Laitala and Boks 2012). Conventional cotton production has high water consumption and employs the use of toxic chemicals that may harm human health and the environment (Allwood et al. 2006). Chemicals are also released in wastewater from processes such as pre-treatments, dyeing, finishing, and laundry. These chemicals are disruptive to both the environment and aquatic-based life (Ruskino 2007). Solid waste is produced during natural fiber yarn, textile, and apparel manufacturing and disposal of apparel products at the end of their life. There are significant issues with clothing waste as the majority of clothing and textile wastes ends up in landfills as opposed to being recycled or reused (Goworek 2011). However, environmental impacts cannot be addressed once the product is introduced into the market and more attention should be focused on ecoenvironmentally friendly product design. Improvements in product design can be made by improving the flow of life cycle information and eco-design guidelines, integrating environmental considerations into the manufacturing processes, and involving relevant stakeholders to review the approach (Steinberger et al. 2009). Education on the need for eco-friendly products and the use of case studies and examples would help to strengthen the design and manufacture of environmentally sustainable products. European Commission-Health and Consumers, Scientific Committees Opinion (1999).

\section{Impact of materials selected to eco-sustainability}

Of all the life stages, the apparel industry has concentrated its environmentally responsible innovation in developing eco-friendly materials, for some understandable reasons. Material choices incorporate the environmental impacts of the production of those materials into the apparel product's life cycle and affect how the garments can be processed, cared for, and disposed (Lewis and Chem 2006). The environmental concerns for materials include energy consumption, use of toxic chemicals, ethics, and sustainability of resource consumption (Muthu et al. 2009). In order to address these material environmental concerns, eco-friendly apparel designers must strive to minimize non-renewable resource and energy use, as well as waste, while utilizing materials that are nontoxic and ethically produced. These materials should also provide valuable characteristics to the consumer, require low-impact care, and be effectively disposed through reuse, recycling, energy reclamation, or composting (Goan 1996). The apparel designer's primary material is of course fabric that can be composed of various fiber types that have unique properties and production. The two principal fiber types are natural fibers from plant cellulose and animal proteins and manufactured fibers derived from natural and synthetic polymers. Fibers are either cultivated, manufactured, or a combination of both. Each fiber source and production method come with its own set of environmental concerns, yet all can be improved to various degrees of reduced environmental harm by either employing best practices in current systems, implementing new, more effective technologies, or replacing current materials and practices with eco-friendly alternatives.

\section{Impact of manufacturing processes to environmental sustainability}

Clothing production is a multi-step procedure that often includes spinning, weaving, knitting, pre-treating, dyeing and/or printing, finishing, and makeup (cut-sew-trim). During these stages, the apparel product is subjected to various chemical treatments, many of which have been highly toxic and non-degrading, but now are sometimes replaced by more nontoxic and biodegradable counterparts (Kadolph 2010). Some fiber processing standard exists that prohibit the use of hazardous chemicals, including the Organic Trade Association's (OTA), American 
Organic Standards for Fiber Processing (Murray and Coody 2003), and the Global Organic Textile Standard (GOTS). Each production stage demands energy and often water to apply treatments, which then require more energy to dry the product after treatment. And lastly, the working conditions at each stage can pose health and safety risks due to exposure to toxic chemicals and air and noise pollution. Eco-friendly apparel production uses resources and energy effectively, only uses nontoxic cleaners and applications. Water is used during many fabric production stages for cleaning and application of dyes and finishes, resulting in large amounts of problematic wastewater (Nese and Ismail 2007). This wastewater can contain washed away dirt and wax from natural fibers, cleaning chemicals, auxiliaries, etc. Most wastewater is dumped rather than treated due to the expense, causing disruptions in the local environment and contaminating the fresh water supply. Dyeing can be done at almost any stage, from the fiber to the constructed product, and may require whitening pre-treatment (Ruskino 2007). Dyes and printing inks require a pigment and a fixative, or mordant, both of which can utilize toxic chemicals and heavy metals. Azo group chemicals, which release carcinogenic arylamines, are widely used in synthetic dyes and pigments. Dyes are difficult to remove from wastewater and leave it colored, preventing wastewater from supporting plant life by inhibiting aquatic plants' ability to photosynthesize. Eco-friendly alternative color options include low-impact and natural dyes that use nontoxic mordants, water-based inks, and color-grown cotton and wool fibers, although the color-grown palates are often muted and limited (Challa 2014). Finishing occurs after the fabric is made and often implies the application of chemicals to the fabric to give it enhanced properties, either esthetic or functional. This process often requires water for the application and to wash out the excess finish. Many finishing processes have been redesigned to use less water or foam substitute, although they still need to be improved to reduce water use and increase wastewater processing. Toxic chemical finishes pose human health risks while their wastewater disrupts ecosystems, yet more finishes are being replaced with less toxic, biodegradable alternatives. Certain finishes can also require the garment to be "dryclean only," which uses cleaning solvents with toxic chlorine chemicals. Conversely, finishes can make traditionally dry clean only fibers, like wool and silk, washable. Some, such washable finishes are toxic chemicals while other uses environmentally safe, natural enzymes (Chen and Burns 2006). Make-up, also known as cut-make-trim, involves cutting the garment pattern out of fabric, sewing it together, and then adding any trim or embellishments. By eliminating waste in the overall process, the product's manufacturing sustainability can be increased remarkably (Islam et al. 2014). Wastages from cutting can vary between 6 and $25 \%$, depending on the complexity of the pattern, although this cutting waste is often recycled into low-quality textile products (Laursen et al. 2007). The apparel industry still relies heavily on human labor as no machinery has been able to reproduce the agility and intricacy of a human producer.

\section{Introduction to the Sustainable Apparel Coalition and Higg Index tool}

The world's textile and apparel industry cover various areas that include the manufacturing, marketing, and retailing of textiles and garment products. This industry has been considered as an approach for industrialization, economic progress, and national development. According to the World Trade Organization, China has been leading the world with regard to export in the field of textiles and apparel, followed by the European Union and India (Wolf et al. 2011). Despite many recent recessions, strategic policies taken in this sector have saved the industry from various problems. Every industry should concentrate on keeping stock levels low, as well as on being flexible and in fine tune with the consumer's needs and wants, emphasizing lean management and strong supply chain networks. Ecological friendliness is the main motto and consumers have been very much aware of its impact, seeking out products that complied with ecological standards (Speer 2005). However, the Sustainable Apparel Coalition (SAC), which helps industries to rate their products with a numerical sustainability, scores in order to provide data to customers with regard to the extent the manufacturer has contributed to the conservation of the environment. SAC (2013) The Higg Index is one such tool for the assessment of product's sustainability, which raises a manufacturer's consciousness of the design, choice of raw materials, manufacturing processes, and finishing, packaging, and distribution through the use and recycling of the product (Martin 2013; Reichard 2013). The SAC is a multistakeholder engagement, formed in 2011, by a group of global apparel and footwear companies and non-profit organizations representing nearly one third of the global market share for apparel and footwear. They seek to build a common approach for measuring and evaluating apparel and footwear product sustainability performance (Ulibarri 2011). It aims to develop common measurements and a common environmental understanding of a product impact across the industry by building on the Outdoor Industry Association (OIA)'s, Eco Index ${ }^{\text {max }}$, and Nike's Environmental Design tool (Nike Inc. 2012c). The Eco Index ${ }^{\text {Tm }}$ is a standardized tool for measuring the environmental impacts of outdoor products such as clothing and tents and evaluates the impacts in six key areas of a product's life cycle, namely materials, packaging, product manufacturing and assembly, transport and distribution, use of services, and end of life 
(Nike Inc. 2012c). Measuring environmental performances of apparel products will spotlight priorities for action and opportunities for technological innovation. SAC (2013c) The Higg Index is an "indicator based tool for the apparel that enables companies to evaluate material types, products, facilities and processes based on a range of environmental product design choices" (The Higg Index 2012). The Higg Index is a set of assessment tools that are used to evaluate the environmental impact of apparel and footwear products. The index was initially released on 26 June 2012 as the Higg Index 1.0, and it has been used by many organizations-both SAC members and nonmembers. The Higg Index 1.0 used a Microsoft Excel interface and worked on qualitative indicators for assessment. The sustainability topics were related to the environment, and the product category was apparel. Approximately 44 materials were included in the material assessment data, and the material sustainability index used basic indicator questions on the environment. The Higg Index version 2.0 is the updated version of 1.0 and was released on 11 December 2013. It is based on tools such as the Eco Index, Nike's Apparel Environmental Design Tool, Global Social Compliance Program reference tools, and social/labor practice tools. After a pilot testing period and use of the second version by many organizations for over 14 months, the Higg Index 2.0 was introduced SAC (2013b). This tool helps to standardize the methodology for measurement and evaluation of the environmental performance of the apparel products along the supply chain in three levels-namely the brand, product, and facility levels. The scope of the Higg Index 2.0 is to assess the environmental and social/labor performance of apparel and footwear products. It is based on life cycle analysis spanning the entire lifecycle of apparel products, encompassing raw materials, manufacturing, packaging, transportation, use, and end of life. The Higg Index 2.0 is a tool that educates small and large companies to recognize challenges and sustain improvement. The self-assessment tool helps scientific learning by means of identifying the vital aspects of environmental sustainability and opportunities that will provide improvement. This index is the basis for future operations and efforts to ensure sustainability and also the starting point for the commitment, learning, and collaboration among stakeholders. The scope of the desired outcomes of the SAC Higg Index tool includes improvement to reduce water use and improve quality, reduce energy and emissions, minimize waste, reduce chemicals and toxicity, and increase transparency of social and labor issues (Ruskino 2007). The tool evaluates material type, products, facilities, and processes. By utilizing practice based, qualitative binary yes/no questions, assessment can be made as to the sustainability performance of the product and drive behavior for improvement. The Higg Index RDM-Beta is a prototype which aims at educating and providing quick directional guidance to apparel designers during the product creation process about the potential environmental impacts of their design solutions (SAC 2013a). It is to engage designers in the Higg Index's product life cycle thinking and how we directionally assess materials sustainability through the MSI. Through self-assessment, organizations can better understand the environmental impacts that occur throughout the life cycle and the effects of design choices such as material type SAC (2012i). However, there are many apparel brands belonging to the Higg Index such as: H\&M, Gap Inc., Nike, Adidas, Puma, Patagonia, Mountain Equipment Co-op (MEC), Levi's, Hanesbrand, Marks and Spencer, Esprit, Columbia, Timberland, Loomstate, S. Oliver, and many such bold face names. These brands are widely using this Higg Index tool to measure environmental performance of their apparel products towards better sustainability of their products (Reuben 2013).

\section{Methods}

To carry out this study, selected knitted men's T-shirt products of $100 \%$ cotton single jersey fabric was taken into consideration as a case study. Both foreign and local branded knitted men's "M" sized short sleeve T-shirt products from some renowned brand were selected on a random basis to measure their environmental performance. The brand B-, C-, and D-named T-shirts were collected from an apparel industry named Viyellatex Group Ltd. T-shirts from brand $\mathrm{E}$ and $\mathrm{F}$ were collected from Beximco fashion wear and Aarong. BUTex-Innovation T-shirt was developed by the researcher as eco-friendly product which is indicated as brand A in this study. However, environmental sustainability of mentioned branded T-shirt was evaluated based on mainly two aspects only. One is to perform selected eco-friendly tests and another is an evaluation of the products by SAC Higg Index tools. Although, some other aspects are related to a fully environmentally sustainable apparel product.

\section{Product environmental aspect test procedures}

To evaluate environmental sustainability of base materials, an initiative was taken to carry out the eco-friendly test of product base body fabric that included formaldehyde, $\mathrm{pH}$ value, analysis of amines in azo dyestuff content, and alkylphenol ethoxylate (APEO) content test. These entire eco-friendly tests were performed as per standard test procedure. The standard test procedure followed for various test were the following: for formaldehydes - International Standard ISO 14184-1: 2011 (for textile and non-woven), for pH-ISO 3071:2006 extraction with potassium chloride (for textiles), for analysis of amines in azo dyestuffs - European Standard EN 14362-3: 2012, (For textile) and for alkylphenol ethoxylate (APEO) content - methanol extraction and analysis 
of by liquid chromatograph mass spectrometer (LC-MS). If the test results are out of range expected as per standard, then that products is termed as harmful to environmental sustainability in that aspect.

\section{T-shirt materials and manufacturing environmental aspect} evaluation by SAC Higg Index tool

All the six T-shirt products were evaluated by the SAC Higg Index tool that provides a value that represents how environmentally responsible an apparel item is in terms of sustainability. For this study, the tool Higg Index was used to obtain product scores for the abovementioned T-shirts. The final score was obtained by answering questions relating to the product materials and manufacturing environmental sustainability issues. The data used during this process include information readily available to the manufacturers, suppliers, merchandisers including hang tags, care labels, and product technical package descriptions, and throughout the LCA phase of the T-shirt. The product technical package detail information was the important source for various Higg Index-required information towards eco-sustainability evaluation. Higg Index requires that all materials present be entered into a material input table along with ecomanufacturing issues. This includes a description of all materials used in addition to information obtained from follow-up questions. By utilizing practice-based, qualitative binary yes/no questions, assessments were made as the sustainability performance of the product and drive behavior for improvement. Higg Index is a Microsoft Office Excel and web-based tool that has predetermined standard values based on a global survey for specific materials that are used in determining a score. Various links between inputs and outputs considered were based on Higg Index tools as the tool has predetermined standard values based on global survey and mathematical model for specific materials and manufacturing process issues. The higher the Higg Index score, the better the environmental performance of an apparel products.

\section{Results and discussion}

In this study, the all five selected foreign and local branded knitted T-shirts along with newly developed one were assessed using the Higg Index 1.0 tools to obtain a value that represents a product's environmental sustainability especially in material and manufacturing issues. A higher score implies a more sustainable product, and a lower score implies less sustainability. Upon completion of the excel-based Higg Index tool, the brand $\mathrm{A}, \mathrm{B}, \mathrm{C}, \mathrm{D}, \mathrm{E}$, and $\mathrm{F}$ T-shirts received different scores on a scale of 1-100. The superior score of the BUTex-Innovation (brand A) and the foreign branded products, especially the brand B-shirt, was due to the organic material content, eco-friendly raw materials and process used product end of life options and confirmed traceability. On the other hand, the local branded Tshirt gained comparatively lower score in most of the areas due to not using eco-friendly raw materials, manufacturing processes, high-impact finishes, improper or insufficient care and repair instructions, and traceability issues. This also assisted to find out various gaps regarding apparel product materials and manufacturing issues and to take steps to improvement of superior clothing product in terms of sustainability.

\section{Results for environmental evaluation test of T-shirt product}

Environmental issues are playing an increasingly important role in consumer products. Textiles and clothing are also subjected to stringent examination, particularly with regard to the chemicals used in their manufacture as they are often in direct contact with the skin. The consumer is confronted with scare stories of health risks and pollution allegedly originating from modern textiles treated with "poisonous, allergenic, or carcinogenic dyes and finishing auxiliaries". Such gross misrepresentation is completely untrue for textile production in countries, where extensive environmental and chemical pollution laws exist (GB 18401 2010). Nevertheless, it cannot be ruled out that some textiles of uncertain origin traded on international markets may have been processed inadequately and may contain residues of untested, possibly hazardous, auxiliaries and dyes. In light of this, the responsible partners in the textile industry believe that it is important to reassure consumers about textiles in human ecological terms, i.e., to reassure the public that properly processed textile products present no health risks (GB 18401, 2010). However, various eco-friendly tests performed for the above selected T-shirt product item showed significant difference.

\section{Formaldehyde test}

Formaldehyde has allergenic and sensitizing effects, even at low concentrations. Levels of $300-\mathrm{mg} / \mathrm{kg}$ formaldehyde on a garment can trigger allergic effects in sensitized individuals. Formaldehyde has an irritant effect on the respiratory tract and mucous membranes in concentrations above $0.5 \mathrm{mg} / \mathrm{m}^{3}$ air. Test method followed for formaldehyde is the International Standard ISO 14184-1: 2011 (for textile and non-woven). The Tshirts of A, B, C, and D brands showed better results in formaldehyde detection with value 11.42, 20.47, 17.82, $32.45 \mathrm{ppm}$, respectively. But a local branded T-shirt of $\mathrm{E}$ and $\mathrm{F}$ brand showed poor results with higher value, i.e., 46.23 and $62.35 \mathrm{ppm}$, respectively. Results are shown in Table 1. 
Table 1 Results of product eco-friendliness test for various selected brand

\begin{tabular}{llcll}
\hline Branded T-shirt & $\begin{array}{l}\text { Results of formaldehyde test } \\
\text { (in ppm). (Detection limit: 16 ppm) } \\
\text { (Maximum limit: 75 ppm) }\end{array}$ & $\begin{array}{l}\text { pH value test (Maximum } \\
\text { limit: 4.0-7.5 ppm) }\end{array}$ & $\begin{array}{l}\text { Results of analysis of amines } \\
\text { in azo dyestuffs (in ppm) } \\
\text { (Detection limit: 10 ppm) }\end{array}$ & $\begin{array}{l}\text { Results of alkylphenol ethoxylate (APEO) } \\
\text { content test in ppm (Detection limit: } \\
30 \text { ppm) (Maximum limit: 100 ppm) }\end{array}$ \\
\hline Brand A & 11.42 & 6.4 & Not detected & Not detected \\
Brand B & 20.47 & 5.7 & Not detected & Not detected \\
Brand C & 17.82 & 6.2 & Not detected & Not detected \\
Brand D & 32.45 & 5.5 & 13.5 & Not detected \\
Brand E & 46.23 & 7.4 & 31.7 & 47.6 \\
Brand F & 62.35 & 7.5 & 43.2 & 64.3
\end{tabular}

Various test methods-formaldehyde test method: International Standard ISO 14184-1: 2011 (for textile and non-woven); pH value test method: ISO 3071:2006 extraction with potassium chloride (for textiles); analysis of amines in azo dyestuff test method: European Standard EN 14362-3: 2012. (for textile); alkylphenol ethoxylate (APEO) content test method: methanol extraction and analysis of by liquid chromatograph mass spectrometer (LC-MS) (for textile)

\section{pH value test}

The $\mathrm{pH}$ value of an aqueous extract of the textile article is determined according to ISO 3071. The required $\mathrm{pH}$ range corresponds approximately to the natural $\mathrm{pH}$ value of human skin (approximately 5.5). This avoids skin irritation due to the release of acidic or alkaline substances from damp textiles. The $\mathrm{pH}$ maximum limit for safe textile materials is 4.0-7.5. However, the tested $\mathrm{pH}$ value results for various branded T-shirts were 6.4, 5.7, 6.2, 5.5, 7.4, and 7.5 for brand A, B, C, D, E, and F T-shirts, respectively (Table 1 ). Also, noticed that the $\mathrm{pH}$ value for local brand $\mathrm{E}$ and $\mathrm{F}$ T-shirts was above 7.0.

\section{Analysis of amines in azo dyestuffs}

Azo dyes are compounds characterized by their vivid colors and provide excellent coloring properties. They are important and widely used as coloring agents in the textile and leather industries. The risk in the use of azo dyes arises mainly from the breakdown products that can be created in vivo by reductive cleavage of the azo group into aromatic amines. Due to the toxicity, carcinogenicity, and potential mutagenicity of thus formed aromatic amines, the use of certain azo dyes as textile colorants and the exposure of consumers using the textile colored with azo compounds cause a serious health concern. The two main routes of consumer exposure are the skin absorption of the azo compounds from the dyed clothes worn and potential oral ingestion, mainly referring to the sacking of textiles by babies and young children. In this study, test method followed by analysis of amines in azo dyestuffs is the European Standard EN 14362-3: 2012 (for textile). From Table 1, it is seen that the $\mathrm{A}, \mathrm{B}$, and $\mathrm{C}$ branded $\mathrm{T}$-shirts showed better results i.e., no detection of such substances, but in D, E, and F branded T-shirts, these substances were detected with values $13.5,31.7$, and $43.2 \mathrm{ppm}$, respectively. Use of ecofriendly raw materials and third party certified dyes and chemicals may add to better results for $\mathrm{A}, \mathrm{B}$, and $\mathrm{C}$ branded T-shirts.

\section{Product test for alkylphenol ethoxylate (APEO) content}

Analyses for APEO have been a fast growing issue of textile material testing. Surprisingly to the producers, APEOs have been detected in rather high amounts in textiles. The most important APEOs or alkylphenol ethoxylates for the textile industry are NPEOs (nonylphenol ethoxylates) and OPEOs (octylphenol ethoxylates) due to their detergent properties. About $90 \%$ of the produced APEOs are in fact NPEOs. The compounds are used in detergents, cleaning agents, or chemicals used for textile or leather production. Toxicological characteristics are their hormone-disruptive properties and the fact that they are toxic to aquatic organisms (Ljungberg 2007). Furthermore, APEOs are very persistent and difficult to be degradable in nature. These are all problem areas for wastewater treatment and discharging of wastewater into surface water. In this study, standard test method followed for textile is methanol extraction and analysis of by liquid chromatograph mass spectrometer (LC-MS). No detection of APEO was found for A, B, C, and D branded T-shirts due eco-friendly dyes and chemicals used in manufacturing processes. Alternatively, a value of 47.6 and $67.3 \mathrm{ppm}$ was detected for $\mathrm{E}$ and $\mathrm{F}$ branded T-shirt test which might be due to environmentally harmful dyes and chemicals and raw material selection in manufacturing stages. Table 1 presents the result details for APEO test.

\section{Test results for various branded T-shirts}

\section{Higg Index evaluation results for materials}

The materials selected for the knitted T-shirt for both foreign and local branded products were entered into the material input table in the Higg Index tool. The values obtained by various products are shown in Table 2 . The developed men's T-shirt $A$ and foreign brand $B, C$, and D obtained higher score. This was due to the eco-friendly raw materials used, i.e., brand $\mathrm{A}$ and $\mathrm{B}$ T-shirt included $100 \%$ organic cotton fiber. During processing of fabric, BUTex-Innovation T-shirt, B-, and other foreign branded T-shirt used eco-friendly, third party verified and environmentally low-impact dyes and chemicals. But in the case 
Table 2 Total materials sustainability score for A and B branded T-shirts

\begin{tabular}{|c|c|c|c|}
\hline $\begin{array}{l}\text { Materials eco-sustainability } \\
\text { scoring issues }\end{array}$ & $\begin{array}{l}\text { Resultant answer } \\
\text { (For A and B brand) }\end{array}$ & $\begin{array}{l}\text { Obtained materials } \\
\text { Score points }(\mathrm{A})\end{array}$ & $\begin{array}{l}\text { Obtained materials } \\
\text { Score points (B) }\end{array}$ \\
\hline Materials name & Fabric (100 \% organic cotton knit fabric & 28.2 (out of 50 ) & 28.2 (out of 50 ) \\
\hline Certified recycled content \% & $0 \%$ & 0.0 & 0.0 \\
\hline Virgin, certified organic content \% & $100 \%$ & 10.0 & 10.0 \\
\hline $\begin{array}{l}\text { Other source certification or verified } \\
\text { chain of custody with name }\end{array}$ & Yes, GOTS, BCl certified & 7.0 & 7.0 \\
\hline $\begin{array}{l}\text { Coating/laminate finish? } \\
\text { (If yes, specify type) }\end{array}$ & No & 4.0 & 4.0 \\
\hline $\begin{array}{l}\text { Reduced water use in dyeing/coloring? } \\
\text { (If yes, specify reduced water } \\
\text { process/technology) }\end{array}$ & $\begin{array}{l}\text { Yes, used process or technology that } \\
\text { reduces water consumption (and reduction } \\
\text { is documented), eco-friendly dyes and } \\
\text { chemicals used, enzymatic scoring used }\end{array}$ & 5.0 & 5.0 \\
\hline $\begin{array}{l}\text { Chemical impact reduction } \\
\text { ("green chemistry") considered? }\end{array}$ & Yes & 4.5 & 4.5 \\
\hline \multirow[t]{2}{*}{ Green chemistry third party verification? } & $\begin{array}{l}\text { "Yes" OEKO-Tex Standard-100 (class-II) } \\
\text { verified) but "No" for BUTex-Innovation T-shirt }\end{array}$ & 0.0 & 4.5 \\
\hline & & 58.8 (out of 100 ) & Total $=3.3$ (out of 100 ) \\
\hline
\end{tabular}

of local branded E and F T-shirt, the Higg Index score was lower due to environmentally hazardous conventional raw materials, processing, poor quality dyes used, no third party verification and such types, and many other issues. For better environmental sustainability, these issues must be addressed for local branded apparel products. Obtained score out of 100 points by A, B, C, D, E, and F branded Tshirts are 63.3, 58.8, 51.6, 46.6, 39.6, and 30.6, respectively. Major variation issues in scoring of branded T-shirt by Higg Index are shown in Tables 3 and 4.

The material sustainability index (MSI) also examines chemistry, energy, and GHG intensity, water- and landuse intensity, and physical waste across the entire cradle-to-gate life cycle of a material. Land-use intensity focuses solely on the origin of a raw material in phase 1 and does not consider land use elsewhere in the material life cycle. The MSI compiles and scores data for $100 \%$ cotton knit (For A, B, C, D, E, and F branded products) fabric based on standard global survey data compiled and established by 13 individual indicators within the various impact areas SAC (2013a).

\section{Higg Index evaluation results for manufacturing stages}

The manufacturing stage is obviously an important area for better product sustainability. Some major issues have huge impact on product environmental sustainability as

Table 3 Total materials sustainability score for C and D branded T-shirts

\begin{tabular}{|c|c|c|c|c|}
\hline \multirow{2}{*}{$\begin{array}{l}\text { Materials eco-sustainability } \\
\text { scoring issues }\end{array}$} & \multicolumn{2}{|l|}{ Resultant answer } & \multirow{2}{*}{$\begin{array}{l}\text { Obtained materials } \\
\text { Score points }(C)\end{array}$} & \multirow{2}{*}{$\begin{array}{l}\text { Obtained materials } \\
\text { Score points }(D)\end{array}$} \\
\hline & C branded T-shirt & D branded T-shirt & & \\
\hline Materials name & Fabric (100\% cotton knit fabric & Fabric $(100 \%$ cotton knit fabric & 26.6 (out of 50 ) & 26.6 (out of 50 ) \\
\hline Recycled content \% & $0 \%$ & $0 \%$ & 0.0 & 0.0 \\
\hline Virgin, certified organic content \% & $0 \%$ & $0 \%$ & 0.0 & 0.0 \\
\hline $\begin{array}{l}\text { Other source certification or } \\
\text { verified chain of custody with }\end{array}$ & Yes, GOTS, BCI certified & Yes, BCl certified & 7.0 & 7.0 \\
\hline $\begin{array}{l}\text { Coating/laminate finish? } \\
\text { (If yes, specify type) }\end{array}$ & No & No & 4.0 & 4.0 \\
\hline $\begin{array}{l}\text { Reduced water use in } \\
\text { dyeing/coloring? (If yes, specify } \\
\text { reduced water process/technology) }\end{array}$ & $\begin{array}{l}\text { Yes, used process or technology } \\
\text { that reduces water consumption } \\
\text { (eco-friendly dyes and chemicals, } \\
\text { enzymatic scoring used) }\end{array}$ & $\begin{array}{l}\text { No, used traditional dyeing/ } \\
\text { coloring process or technology }\end{array}$ & 5.0 & 0.0 \\
\hline $\begin{array}{l}\text { Chemical impact reduction } \\
(\text { "green chemistry")? }\end{array}$ & Yes & Yes & 4.5 & 4.5 \\
\hline \multirow[t]{2}{*}{$\begin{array}{l}\text { Green chemistry third } \\
\text { party verification? }\end{array}$} & $\begin{array}{l}\text { Yes, OEKO-Tex Standard-100 } \\
\text { (class-II) verified) }\end{array}$ & $\begin{array}{l}\text { Yes, OEKO-Tex Standard-100 } \\
\text { (class-II) verified) }\end{array}$ & 4.5 & 4.5 \\
\hline & & & $\begin{array}{l}\text { Total = } 51.6 \\
\text { (out of } 100 \text { ) }\end{array}$ & $\begin{array}{l}\text { Total }=46.6 \\
\text { (out of } 100 \text { ) }\end{array}$ \\
\hline
\end{tabular}


Table 4 Total materials sustainability score for $\mathrm{E}$ and $\mathrm{F}$ branded T-shirts

\begin{tabular}{|c|c|c|c|c|}
\hline \multirow{2}{*}{$\begin{array}{l}\text { Materials eco-sustainability } \\
\text { scoring issues }\end{array}$} & \multicolumn{2}{|l|}{ Resultant answer } & \multirow{2}{*}{$\begin{array}{l}\text { Obtained materials } \\
\text { Score points (E) }\end{array}$} & \multirow{2}{*}{$\begin{array}{l}\text { Obtained material } \\
\text { Score points }(F)\end{array}$} \\
\hline & E branded T-shirt & F branded T-shirt & & \\
\hline Materials name & Fabric (100\% cotton knit fabric & Fabric (100\% cotton knit fabric & 26.6 (out of 50 ) & 26.6 (out of 50 ) \\
\hline Recycled content \% & $0 \%$ & $0 \%$ & 0.0 & 0.0 \\
\hline Virgin, certified organic content \% & $0 \%$ & $0 \%$ & 0.0 & 0.0 \\
\hline $\begin{array}{l}\text { Other source certification or } \\
\text { verified chain custody and name }\end{array}$ & No & No & 0.0 & 0.0 \\
\hline $\begin{array}{l}\text { Coating/laminate finish? } \\
\text { (specify type) }\end{array}$ & No & No & 4.0 & 4.0 \\
\hline $\begin{array}{l}\text { Reduced water use in } \\
\text { dyeing/coloring? (If yes, } \\
\text { specify reduced water } \\
\text { process/technology) }\end{array}$ & $\begin{array}{l}\text { No, used traditional dyeing/coloring } \\
\text { process or technology }\end{array}$ & $\begin{array}{l}\text { No, used traditional dyeing/ } \\
\text { coloring process or technology }\end{array}$ & 0.0 & 0.0 \\
\hline $\begin{array}{l}\text { Chemical impact reduction } \\
\text { ("green chemistry")? }\end{array}$ & Yes & No & 4.5 & 0.0 \\
\hline \multirow[t]{2}{*}{$\begin{array}{l}\text { Green chemistry third } \\
\text { party verification? }\end{array}$} & $\begin{array}{l}\text { Yes, OEKO-Tex Standard-100 } \\
\text { (class-II) verified) }\end{array}$ & No & 4.5 & 0.0 \\
\hline & & & $\begin{array}{l}\text { Total }=39.6 \\
\text { (out of } 100 \text { ) }\end{array}$ & $\begin{array}{l}\text { Total }=30.6 \\
\text { (out of } 100 \text { ) }\end{array}$ \\
\hline
\end{tabular}

per Higg Index tool. The developed men's T-shirt, B-, and other foreign branded T-shirt used low-impact garment finish, i.e., process combination enzyme wash or basic rinse that scored higher. But local branded F and E T-shirts used high-impact garment finish, namely traditional bleach and acid chemical with stone wash, and scored lower. Besides, marker efficiency has great impact on product sustainability. The higher the marker efficiency, the better the product sustainability; and lower marker efficiency indicates its direct impact on supply chain, including more wastage of material, fabrics, dyes, chemicals, process loss, land fill, etc. As developed BUTex-Innovation brand A, B, C, and D branded T-shirts had more than $91 \%$ marker efficiency, they scored better. But $\mathrm{E}$ and $\mathrm{F}$ branded T-shirts had marker efficiency of 82 and $85 \%$ and scored lower in the Higg Index tool. Similarly, a single colored, screen-printed logo with small area received a higher score for foreign branded $\mathrm{T}$-shirts and these issues vice versa scored lower for local branded Tshirts. The total points for manufacturing stages by various branded T-shirts are 60, 72, 65, 63, 49, and 27 for A, $\mathrm{B}, \mathrm{C}, \mathrm{D}, \mathrm{E}$, and F respectively which is shown in Table 5 .

\section{Integrating issues for environmental sustainability improvement of apparel products}

The researcher has identified many technical requirements and issues for apparel product sustainability improvement based on the Higg Index assessment tool.

\section{Sourcing fair production and practice transparency:}

Sourcing fair production can be performed by selecting manufacturers that are known to operate in an eco- socially responsible manner. For the technical requirement of practicing transparency, the researcher suggests a hang tag including maximum detail information to the product that includes the name and contact information of a hypothetical manufacturer. This would allow a customer to verify environmentally and socially responsible methods practiced when the product was produced.

\section{Consider waste-reducing design and clean manufacturing policy:}

To reduce waste, the researcher suggested using ecofriendly dyeing methods such as reduced water dyeing or waterless dyeing method for the fabric processing. An on-product label with instructions to recycle, reuse of the product, thus reducing waste, should be added to the label. Clean production can be achieved by selecting manufacturers that make a commitment to the use of alternative or renewable energies. Maximum possible marker efficiency should be ensured during product development and manufacturing. Product printing, washing, and other finishing materials and processes should be selected focusing eco-sustainability priorities.

\section{Raw materials:}

Selecting the eco-friendly raw materials is an important aspect for minimizing overall environmental impact throughout the product life cycles. Organic textile farming uses up to $60 \%$ less water than conventional farming methods and were grown without cancer-producing pesticide and insecticide. Organic clothing is made from organic fibers grown without both exposures to toxins and irreversible environmental damage. Key factors of sustainable clothing are the fiber source and renewability 
Table 5 Higg Index evaluation on manufacturing eco-sustainability of various branded T-shirts

\begin{tabular}{|c|c|c|c|c|c|c|c|c|c|c|c|c|}
\hline \multirow{2}{*}{$\begin{array}{l}\text { Manufacturing } \\
\text { eco-sustainability of } \\
\text { various branded T-shirts }\end{array}$} & \multicolumn{6}{|c|}{ Answers of questionnaires } & \multicolumn{6}{|c|}{ Score Point Obtained (out of 100) } \\
\hline & Brand A & Brand B & Brand C & Brand D & Brand E & Brand F & Brand A & Brand B & Brand C & Brand D & Brand $E$ & Brand $\mathrm{F}$ \\
\hline Marker/material efficiency \% & 91 & 93 & 95 & 93 & 85 & 82 & 41 (out of 50) & 43 & 45 & 43 & 30 & 24 \\
\hline Garment finish & Basic rinse & Enzyme wash & Basic softener & Basic softener & Basic softener & Acid chemical wash & 10 (out of 30 ) & 20 & 10 & 10 & 10 & 0 \\
\hline Applied graphics and logo & $10 \mathrm{~cm}^{2}$ or less & $10 \mathrm{~cm}^{2}$ or less & $10 \mathrm{~cm}^{2}$ or less & $10 \mathrm{~cm}^{2}$ or less & $10-100 \mathrm{~cm}^{2}$ & $100-200 \mathrm{~cm}^{2}$ & 6.0 (out of 10 ) & 6.0 & 6.0 & 6.0 & 6.0 & 2.0 \\
\hline Screen printing size and color & $\begin{array}{l}10-100 \mathrm{~cm}^{2} \\
\text { and } 3 \text { color }\end{array}$ & $\begin{array}{l}10-100 \mathrm{~cm}^{2} \\
\text { and } 3 \text { color }\end{array}$ & $\begin{array}{l}10 \mathrm{~cm}^{2} \text { or less } \\
\text { and } 2 \text { color }\end{array}$ & $\begin{array}{l}10 \mathrm{~cm}^{2} \text { or less } \\
\text { and } 2 \text { color }\end{array}$ & $\begin{array}{l}10-100 \mathrm{~cm}^{2} \\
\text { and } 3 \text { color }\end{array}$ & $\begin{array}{l}100-200 \mathrm{~cm}^{2} \\
\text { and } 5 \text { color }\end{array}$ & 3.0 (out of 10 ) & 3.0 & 4.0 & 4.0 & 3.0 & 1.0 \\
\hline Total & & & & & & & 60 & 72 & 65 & 63 & 49 & 27 \\
\hline
\end{tabular}


without the use of agro-chemicals, hormones, and pesticides, along the entire manufacturing process from raw fiber to textile.

\section{Consider natural and low-impact dyes and chemicals:}

The designers, manufacturers, and merchandisers should introduce natural and environmentally low impact dyes in material processing for better product sustainability. Dyes and chemicals used for a product in wet processing, finishing, washing, and printing process should address both environmental concerns and economic realities with consumer demand for greener products.

\section{Conclusions}

The textile and apparel industries are notorious for their excessive contribution of waste and pollution to our environment. The unsustainable practice trends of poor designing, raw material selection, processing, manufacturing, and disposing of apparel products are the major contributing factors to this problem. The purpose of this study was to evaluate the material and manufacturing environmental sustainability of various branded T-shirts and find out various sustainable issues for greener apparel products. Based on eco-friendly test and Higg Index environmental assessment standard tool, the findings of this study could be helpful for many organizations and customers who attempt to produce and consume sustainable textiles and clothing products. Both the local and foreign branded products should be produced by strictly maintaining sustainability issues. Hence, this study is a little approach towards better sustainable practices and eventually would drive the textile and clothing designer, manufacturers, merchandisers, and consumers to introduce various sustainable issues in their works. Hence, this study leads to growing awareness and hopefully would direct them towards sustainable practices in the textile and clothing business for a greener world.

\section{Competing interests}

Both authors declare that they have no competing interest in relation to this study.

\section{Authors' contributions}

MMI and MRK contributed to conception and design of the study. MMI carried out the experiments, analyzed the data as well as drafted the manuscript and MRK supervised the works. Both authors read and approved the final manuscript.

Received: 4 January 2015 Accepted: 7 June 2015

Published online: 17 July 2015

\section{References}

Adams, CA, \& Frost, GR. (2008). Integrating sustainability reporting into management practices.

Allwood, JM, Laursen, SE, de Rodriguez, CM, \& Bocken, NMP. (2006). Well dressed? The present and future sustainability of clothing and textiles in the United Kingdom. Cambridge, UK: University of Cambridge, Institute of Manufacturing.
Challa L (2014) Impact of textiles and clothing industry on environment: approach towards eco- friendly textiles. http://www.fibre2fashion.com/. Accessed 28 June 2014.

Chen, HL, \& Burns, LD. (2006). Environmental analysis of textile products. Clothing and Textiles Research Journal, 24(3), 248-261.

DEFRA (2010). Sustainable clothing action plan. https://www.gov.uk/government/ uploads/system/uploads/attachment_data/file/69193/pb13206-clothingaction-plan-100216.pdf. Accessed 6 July 2014.

European Commission-Health and Consumers, Scientific Committees Opinion, see http://ec.europa.eu/health/scientific_committees/environmental_risks/ opinions/sctee/sct_out27_en.htm, Brussels, 18 January 1999.

Fletcher, K. (2008). Sustainable fashion and textiles. London, UK: Earthscan.

Fletcher, K, \& Grose, L. (2012). Fashion and sustainability: design for change. London: Laurence King Publishing.

GB 18401, (2010) National general safety technical codes for textile products.

Goan, M. (1996). An integrated approach to environmentally conscious design and manufacturing. Doctoral dissertation, Virginia Polytechnic Institute and State niversity, Blacksburg, Virginia.

Goworek, H. (2011). Social and environmental sustainability in the fashion industry: a case study of a fair trade retailer. Social Responsibility Journal, 7(1), 74-86.

Islam, MM, Khan, MMR, \& Elias, K. (2014). American Journal of Engineering Research (AJER), 03(12), 62-68.

IPP (2014) Integrated product policy (IPP). http://ec.europa.eu/environment/ipp/ home.htm. Accessed 25 May 2014

Kadolph, SJ. (2010). Textiles. Upper Saddle River. NJ: Person Education Inc

Laitala, K, \& Boks, C. (2012). Sustainable clothing design: use matters. Journal of Design Research, 10(1), 121-139.

Laursen, S. E., Hansen, J., Knudsen, H. H., Wenzel, H., Larsen, H. F., and Kristensen, F. M. (2007). EDIPTEX: environmental assessment of textiles. Danish Environmental Protection Agency.

Lewis, VD, \& Chem. (2006). The life of a piece of cloth: developing garments into a sustainable service system. International Journal of Environmental, Cultural, Economic and Social Sustainability, 2(1), 197-207.

Ljungberg, LY. (2007). Materials selection and design for development of sustainable products. Materials in Engineering, 28(2), 466-479.

Martin M (2013), Creating sustainable apparel value chains - a primer on industry transformation. http://www.ifc.org/. Accessed 25 Apr 2014

Md. Mazedul Islam and Md. Mashiur Rahman Khan, (2014). Environmental sustainability evaluation of apparel product: a case study on knitted T-shirt. Journal of Textiles. Volume: 2014, 643080, pp: 1-6. http://dx.doi.org/10.1155/2014/643080.

Murray and Coody (2003), Environmental impact of textile production. (I. J. Ulasewicz, Ed.) New York: Fairchild Books, Inc.

Muthu, SS, Li, Y, Hu, JY, \& Mok, PY. (2009). An exploratory eco-impact assessment of paper and plastic bags. Journal of Fibre Bioengineering and informatics, 1(4), 307-320

Muthu, SS, Li, Y, Hu, JY, Mok, PY, Ding, X, Wang, X, \& Weibang, C. (2010). Eco-impact of shopping bags: consumer attitude and government policies. Journal of Sustainable Development, 3, 71-83.

Muthu, SS, Li, Y, Hu, JY, \& Mok, PY. (2012). Quantification of environmental impact and sustainability of textile fibres. Ecological Indicator, 13, 66-74.

Niinimäki, K, \& Hassi, L. (2011). Emerging design strategies in sustainable production and consumption of textiles and clothing. Journal of Cleaner Production, 19(1), 1876-1883.

Nike Inc (2012c) Product design and materials. http://www.nikeresponsibility.com/ report/content/chapter/materials. Accessed 2 Dec 2014

Reichard R (2013) Textiles 2013: the turnaround continues. http://www.textileworld.com. Accessed 1 May 2014.

Reuben, A. (2013). The Higg index for sustainable apparel Environmental Performance Index. Retrieved December 12 from, http://epi.yale.edu/ indicators/indicator-case-studies/reports/higg-index-.

Ruskino, C. (2007). Green manufacturing: an evaluation of environmentally sustainable manufacturing practices and their impact on competitive outcomes. IEEE: Transactions on Engineering Management, 54(3), 445-454.

SAC (2012i) SAC (2013) Material assessment, MSI information, MSI life cycle scope. http://www.apparelcoalition.org/msi/msi-information/msi-environmentalimpact-areas.html. Accessed 8 Apr 2014.

SAC (2013a) Material sustainability index base material score. http://www.apparelcoalition.org/msi/. Accessed 5 May 2014.

SAC (2013c) Material assessment, MSI information, MSI environmental impact areas. http://www.apparelcoalition.org/msi/msi-information/msienvironmental-impact-areas.html. Accessed 2 May 2014. 
Speer, J. (2005). Organic cotton: where, why and how. Apparel. Journal of Sustainable Textiles Material, 46(9), 29-34.

Steinberger, JK, Friot, D, Jolliet, O, \& Erkman, S. (2009). A spatially explicit life cycle inventory of the global textile chain. The International Journal of Life Cycle Assessment, 14(5), 453-455.

USagain (2015). The environmental impact of cotton T-shirt. Retrieved March 15 2015 from https://www.youtube.com/watch?v=g5rGm6veAhg

The Higg Index. (2012). . Retrieved January 10, 2013 from http://www.apparelcoalition.org/higgindex.

Ulibarri S, (2011) sets standards for clothing and footwear. http://www.justmeans. com/blogs/sustainable-apparel-coalition-sets-standards-for-clothing-andfootwear. Accessed 20 May 2014.

Wolf MA, Pant R, Chomkhamsri K (2011), Towards life cycle sustainability management. http://link.springer.com/book/10.1007/978-94-007-1899-9. Accessed 1 March 2014

Submit your manuscript to a SpringerOpen ${ }^{\odot}$ journal and benefit from:

- Convenient online submission

- Rigorous peer review

- Immediate publication on acceptance

- Open access: articles freely available online

- High visibility within the field

- Retaining the copyright to your article

Submit your next manuscript at $>$ springeropen.com 